\title{
Penggunaan Model Pembelajaran Field Trip dalam Meningkatkan Keterampilan Menulis Karangan Deskripsi Bahasa Jerman Siswa
}

\author{
Elfrida Enung dan Misnawaty Usman² \\ Fakultas Bahasa dan Sastra. Universitas Negeri Makassar. \\ E-mail :elfridaenung99@yahoo.com
}

E-ISSN : $2579-4574$

P-ISSN : 2549-7359

\begin{abstract}
The purpose of this study was to know the effectiveness of Field-Trip-Learningmethod in writing a German description essay. This study used quasi-experiment approach. The sample in this study is random sampling. Data is analyzed using t-Test analysis. The result of data analysis shows that $t$-count $8,44>t$-table 2,000 at significant level of 0.05 . The results showed that The Field-Trip-Learning method is effectively used in increasing student's writing skill.
\end{abstract}

Keyowrds: Field Trip Model, Learning Model, Descrption Essay

\section{https://ojs.unm.ac.id/eralingua}

\section{PENDAHULUAN}

Metode pembelajaran Field Trip merupakan metode pembelajaran dimana siswa dan guru berkunjung ke lingkungan sekitar atau berwisata. Maksud dari berwisata adalah cara mengajar yang dilakukan dengan mengajak siswa ke suatu tempat atau objek tertentu di luar sekolah untuk mengetahui atau menyelidiki sesuatu. Dengan metode ini siswa mendapat gambaran secara konkrit mengenai hal-hal yang akan ditulis, antara lain dalam menentukan topik karangan deskripsi. Penggunaan metode Field Trip dalam membuat karangan deskripsi, diharapkan siswa dapat termotivasi untuk mengembangkan imajinasi dalam menuangkan ide, pikiran, dan gagasan sesuai dengan keadaan nyata di lingkungan sekitar ke dalam bentuk tulisan.

Siswanto dan Ariani (2016:117) berpendapat bahwa metode pembelajaran Field Trip adalah metode pembelajaran yang mengajarkan siswa di bawah bimbingan guru mengunjungi tempat-tempat tertentu dengan maksud untuk belajar. Sagala dalam Zulaikoh (2009:44) berpendapat bahwa metode pembelajaran Field Trip adalah metode pembelajaran yang digunakan untuk melengkapi pengalaman belajar tertentu dimana siswa mengunjungi tempat-tempat tertentu untuk mempelajari dan menyelidiki tempat tersebut dengan tujuan untuk belajar. Menurut Roestiyah dalam Zulaikoh (2009:85) metode pembelajaran Field Trip bukan sekadar rekreasi, tetapi untuk belajar atau memperdalam pelajaran dengan melihat kenyataan. Berdasarkan beberapa pendapat tersebut dapat disimpulkan bahwa metode pembelajaran Field Trip adalah metode pembelajaran 
dimana siswa mengunjungi tempat-tempat tertentu dengan maksud untuk belajar guna melengkapi pengalaman belajar siswa.

Metode pembelajaran Field Trip memiliki beberapa kelebihan dan kekurangan. Kelebihan metode pembelajaran Field Trip menurut Djamarah (2006:94) (a) Field Trip memiliki prinsip pengajaran modern yang memanfaatkan lingkungan nyata dalam pengajaran; (b) Membuat apa yang dipelajari di sekolah lebih relevan dengan kenyataan dan kebutuhan masyarakat; (c) Pengajaran serupa ini dapat lebih merangsang kreativitas siswa; (d) Informasi sebagai bahan pelajaran lebih luas dan aktual. Selanjutnya Sagala dalam Zulaikoh (2009: 44-45) kelebihan pembelajaran Field Trip adalah (a) Anak didik dapat mengamati kenyataankenyataan yang beraneka ragam dari dekat; (b) Anak didik dapat menghayati pengalaman-pengalaman baru dengan mencoba turut serta di dalam suatu kegiatan; (c) Anak didik dapat menjawab masalah-masalah atau pernyataanpernyataan dengan melihat, mendengar, mencoba, dan membuktikan secara langsung; (d) Anak didik dapat memperoleh informasi dengan jalan mengadakan wawancara atau mendengar ceramah yang diberikan selama kegiatan pembelajaran berlangsung; (e) Anak didik dapat mempelajari sesuatu secara intensif dan komprehensif.

Selain itu Siswanto dan Ariani (2016:117) kelebihan pembelajaran Field Trip adalah sebagai berikut: (a) Meningkatkan kualitas pembelajaran menulis siswa, ditandai dengan timbulnya keaktifan siswa dalam mengikuti pembelajaran keterampilan menulis; (b) Keaktifan siswa dalam pembelajaran meliputi aktif bertanya maupun memberikan tanggapan, aktif mengerjakan tugas serta menjawab pertanyaan guru; (c) Memudahkan siswa untuk menuangkan ide-ide ke dalam tulisan; (d) Siswa dapat memperoleh pengalaman langsung dari objek yang dilihatnya; (e) Siswa lebih nyaman dan senang ketika pembelajaran berlangsung. Maka dari itu dapat disimpulkan bahwa kelebihan metode pembelajaran Field Trip adalah meningkatkan kualitas pembelajaran menulis siswa serta memudahkan siswa untuk menuangkan ide-ide ke dalam tulisan karena siswa dapat menjawab masalahmasalah atau pernyataan-pernyataan dengan melihat, mendengar, mencoba, dan membuktikan secara langsung.

Adapun kelemahan pembelajaran Field Trip Sagala dalam Zulaikoh (2009: 4546) kelemahan pembelajaran Field Trip adalah sebagai berikut: (a) Memerlukan persiapan oleh banyak pihak; (b) Jika karyawisata sering dilakukan akan mengganggu kelancaran pelaksanaan pembelajaran, apalagi jika tempat-tempat yang dikunjungi jauh dari sekolah; (c) Kadang-kadang terjadi kesulitan dalam pengangkutan; (d) Jika tempat yang dikunjungi itu sukar untuk diamati, akibatnya siswa menjadi bingung dan tidak akan mencapai tujuan yang diharapkan; (e) Memerlukan pengawasan yang tepat; (f) Memerlukan biaya yang relatif tinggi. Selanjutnya Siswanto dan Ariani (2016: 117) kelemahan pembelajaran Field Trip adalah '(a) Membutuhkan waktu yang lama; (b) Membutuhkan biaya yang cukup banyak; (c) Guru membutuhkan tenaga ekstra untuk dapat membimbing siswa satu per satu. disimpulkan bahwa kelemahan metode pembelajaran Field Trip membutuhkan waktu yang lama dan biaya yang cukup banyak serta guru membutuhkan tenaga ekstra untuk dapat membimbing siswa satu per satu. 


\section{KETERAMPILAN MENULIS}

Tarigan (2008:1) berpendapat bahwa keterampilan itu erat berhubungan dengan proses-proses yang mendasari bahasa. Bahasa seseorang mencerminkan pikiranya. Semakin terampil seseorang berbahasa, semakin cerah dan jelas pula pikiranya. Keterampilan hanya dapat diperoleh dan dikuasai dengan jalan praktik dan banyak latihan. Melatih keterampilan berbahasa berarti pula melatih keterampilan berpikir. Muhibbinsyah (2010: 117) berpendapat bahwa keterampilan ialah kegiatan yang berhubungan dengan urat-urat syaraf dan otot-otot (neoromuscular) yang tampak dalam kegiatan jasmaniah seperti menulis, mengetik, olah raga, dan sebagainya. Sedangkan, Zainurrahman (2013:12) mengemukakan bahwa keterampilan dibagi menjadi dua jenis yakni, keterampilan yang bisa diperoleh secara alami dan keterampilan yang diperoleh melalui latihan. Maka dari itu dapat disimpulkan bahwa pengertian keterampilan adalah kegiatan melatih berpikir seseorang yang bisa diperoleh secara alami maupun melalui latihan jasmaniah.

\section{KARANGAN DESKRIPSI}

Dalman (2015:93) mengemukakan bahwa karangan deskripsi adalah bentuk tulisan yang bertujuan memperluas pengetahuan dan pengalaman pembaca dengan jalan melukiskan hakikat objek yang sebenarnya. Deskripsi dimaksudkan sebagai suatu karangan yang digunakan penulis untuk memindahkan kesan-kesannya, memindahkan hasil pengamatan dan perasaannya, dan disajikan kepada para pembaca. Tarigan (2008: 20) menjelaskan bahwa karangan deskripsi merupakan jenis komunikasi tertulis yang menggambarkan suatu objek secara detail sesuai dengan keadaan yang sebenar-benarnya tentang objek yang dilukiskan tersebut. Segala sesuatu yang didengar, dicium, dan dirasa kemudian dengan media kata-kata dilukiskan agar dapat dihayati oleh orang lain. Jauhari (2013:45) juga menambahkan bahwa karangan deskripsi adalah karangan yang menggambarkan atau melukiskan benda atau peristiwa dengan sejelas-jelasnya sehingga pembaca seolah-olah melihat, merasakan, mencium, dan mendengarnya. Maka dari itu dapat disimpulkan bahwa karangan deskripsi merupakan karangan yang melukiskan atau menggambarkan suatu objek secara detail dengan tujuan agar karangan tersebut dapat dihayati oleh orang lain atau pembaca.

\section{METODE PENELITIAN}

Penelitian ini menggunakan dua variabel yaitu variabel bebas $(X)$ dan variabel terikat $(Y)$. Variabel bebas yang dimaksud adalah metode pembelajaran Field Trip dan variabel terikat adalah keterampilan menulis karangan deskripsi. Desain penelitian ini adalah Quasi Eksperimental. Populasi dalam penelitian ini adalah seluruh siswa kelas XI MIPA SMA Negeri 8 Makassar yang terdiri dari 5 kelas, dengan jumlah siswa 165 orang. Sampel penelitian ini adalah kelas XI MIPA 1 yang berjumlah 31 siswa sebagai kelas eksperimen dan kelas XI MIPA 2 yang berjumlah 31 siswa sebagai kelas kontrol. 


\section{HASIL DAN PEMBAHASAN}

Sampel yang digunakan dalam penelitian ini adalah random sampling yaitu kelas XI MIPA 1 sebagai kelas eksperimen dan kelas XI MIPA 2 sebagai kelas kontrol. Pembelajaran dilakukan sebanyak 4 kali pertemuan setelah pemberian pre-test pada masing-masing kelas. Pembelajaran pada kedua kelas tersebut dilakukan secara berbeda, siswa pada kelas eksperimen diajar dengan menggunakan metode pembelajaran Field Trip dan siswa pada kelas kontrol diajar menggunakan metode ceramah. Pre-test diberikan untuk mengetahui kemampuan awal siswa dalam keterampilan menulis karangan deskripsi dan hasilnya menunjukkan bahwa kelas eksperimen (XI MIPA 1) memeroleh nilai rata-rata (mean) sebesar 62,16. Hasil analisis menunjukkan bahwa 3 siswa (9,68\%) yang memperoleh nilai terendah yaitu 29 dan 6 siswa (19,35\%) yang memeroleh nilai tertinggi yaitu 86. Kelas kontrol (XI MIPA 2) memeroleh nilai rata-rata 59,36, hasil analisis menunjukkan bahwa 3 siswa $(9,68 \%)$ memeroleh nilai terendah yaitu 29 dan 3 siswa (9,68\%) memeroleh nilai tertinggi yaitu 86.

Hasil nilai pre-tes tersebut kemudian di uji dengan menggunakan uji normalitas dan uji homogenitas. Uji normalitas untuk mengetahui apakah kedua sampel yang diteliti berdistribusi normal atau tidak. Hasil analisis data menunjukkan bahwa distribusi pre-test kelas eksperimen dan kelas kontrol dinyatakan normal. Artinya, tes yang diberikan sesuai dengan kemampuan siswa. Adapun hasil uji homogenitas menunjukkan bahwa nilai F-hitung pada kelas eksperimen dan kelas kontrol adalah 1,02. Hasil tersebut dibandingkan dengan F-tabel ( $d k=5$, taraf signifikan 0,05) sebesar 5,050. Hal ini menunjukkan bahwa F-hitung lebih kecil dari Ftabel $(1,02<5,050)$. Hal ini berarti bahwa kelompok data pada kelas eksperimen dan kontrol dinyatakan homogen. Pemberian treatment pada kelas eksperimen dengan metode pembelajaran Field Trip dan pada kelas kontrol menggunakan model pembelajaran konvensional. Setelah 4 kali pertemuan, kedua kelas tersebut kembali diberi tes (post-test) keterampilan menulis karangan deskripsi bahasa Jerman. Hasil post-test pada kelas eksperimen (XI MIPA 1) yang diajar dengan menggunakan metode pembelajaran Field Trip mengalami peningkatan nilai yang signifikan. Hal ini dapat dilihat dengan perolehan nilai untuk kelas eksperimen: 6 siswa (19,35\%) memeroleh nilai terendah yaitu 57 yang sebelumnya yaitu 29 dan 6 siswa (48,39\%) yang memeroleh nilai tertinggi yaitu 86 dengan rata-rata 75,55 yang sebelumnya hanya 62,16 . Siswa telah mampu menulis karangan deskripsi sesuai dengan pertanyaan yang diajukan guru. Tetapi masih terdapat sedikit kesalahan dalam penyusunan kalimat, seperti tanda baca, pemilihan kosakata, huruf kapital pada awal kalimat ataupun paragaraf dan juga penulisannya, namun kemampuan siswa lebih meningkat setelah pembelajaran dengan Field Trip.

Adapun kelas kontrol yang belajar dengan menggunakan metode ceramah tidak mengalami peningkatan nilai yang signifikan. Perolehan nilai menunjukkan bahwa 4 siswa (12,90\%) memeroleh nilai terendah yaitu 29 dan 1 siswa (3,23\%) memeroleh nilai tertinggi yaitu 86 . Dengan nilai rata-rata 50,26. Tidak seperti pada kelas eksperimen, pada kelas kontrol siswa masih banyak melakukan kesalahan dalam menulis karangan deskripsi seperti; struktur kalimat, konjugasi, pemilihan kosakata dan juga penulisannya. Selanjutnya, dilakukan pengujian dengan 
menggunakan uji-tuntuk mengetahui hasil akhir dari penelitian ini, yaitu ada tidaknya perbedaan tingkat keterampilan Karangan Deskripsi bahasa Jerman pada hasil post-test kelas eksperimen dan kelas kontrol.Hasil penghitungan tersebut diperoleh data bahwa thitung sebesar 8,44 . Setelah dibandingkan dengan ttabel pada taraf signifikansi 0,05 dan dk 60 sebesar 2,000 maka dapat disimpulkan bahwa t-hitung (t-hitung) lebih besar daripada t-tabel (t-tabel) yakni thitung $(8,44)>t$-tabel $(2,000)$. Dengan demikian, Ho yang berbunyi: metode pembelajaran Field Trip tidak efektif dalam keterampilan menulis karangan Deskripsi bahasa Jerman siswa kelas XI SMA Negeri 8 Makassar ditolak. Konsekuensinya, H1 yang berbunyi metode pembelajaran Field Trip efektif dalam keterampilan menulis Karangan Deskripsi bahasa Jerman siswa kelas X1 SMA Negeri 8 Makassar diterima.

\section{KESIMPULAN}

Metode pembelajaran Field Trip efektif dalam pembelajaran keterampilan menulis karangan deskripsi bahasa Jerman siswa kelas XI SMA Negeri 8 Makassar. Hal ini dapat dilihat dari hasil perhitungan uji-t terhadap nilai post-test siswa. Adapun hasil analisis uji-t yaitu, t-hitung $=8,44>$ ttabel $=2,000$ pada taraf signifikansi 0,05. Pembuktian ini menunjukkan bahwa metode pembelajara Field Trip efektif dalam keterampilan menulis Karangan deskripsi bahasa Jerman siswa kelas XI SMA Negeri 8 Makassar.

\section{DAFTAR PUSTAKA}

Dalman. (2015). Penulisan Populer. Jakarta: PT. Raja Grafindo Persada. Djamarah. (2006). Model Pembelajaran Field Trip. Jakarta: Foxit Coorporation. Jauhari, Heri. (2013). Terampil Mengarang. Bandung: Nuansa Cendekia.

Siswanto, Wahyudi dan Ariani, Dewi. (2016). Model Pembelajaran Menulis Cerita. Bandung : PT Rafika Aditama

Tarigan, Henry Guntur. (2008). Menulis. Bandung: Percetaan Angkasa.

Zainurrahman. (2013). Menulis: dari Teori Hingga Praktik. Bandung: Alfabeta.

Zulaikoh, Siti. (2009). Penerapan Metode Field Trip untuk Meningkatkan Kemampuan Menulis Deskripsi pada Siswa Kelas X-1 SMA Negeri 1 Ngemplak Kabupaten Boyolali. Skripsi. Surakarta. 